\title{
Overweight and obesity significantly reduce pregnancy, implantation, and live birth rates in women undergoing In Vitro Fertilization procedures
}

\author{
Javier García-Ferreyra ${ }^{1}$, Jorge Carpio ${ }^{1}$, Milton Zambrano ${ }^{1}$, Pedro Valdivieso-Mejía ${ }^{1}$, Pedro Valdivieso-Rivera ${ }^{1}$ \\ ${ }^{1}$ Laboratory of Assisted Reproduction. Alcívar Hospital, Guayaquil, Ecuador
}

\begin{abstract}
Objective: The objective of this study was to evaluate the effects of overweight and obesity on fertility outcomes in IVF procedures.

Methods: This was a retrospective and nonrandomized study that included 191 IVF/ICSI cycles using non-donor oocytes performed between July 2016 and December 2018 that were allocated according to Body Mass Index (BMI) in three groups: Normal group: 18.5-24.9 ( $n=67$ women), Overweight group: $25.0-29.9(n=86$ women) and Obesity group: $\geq 30.0$ ( $n=38$ women). We compared fertilization rates, embryo quality at day 3 , development and quality of blastocyst, pregnancy rates, implantation rates, and live birth rates.
\end{abstract}

Results: Patients from all groups had similar stimulation days, but those women with overweight and obesity used more hormones compared to women with normal weight $(p<0.05)$. Fertilization rates, zygotes that underwent cleavage and good-quality embryos at Day 3 were similar between the three evaluated groups. The groups of overweight and obesity had embryos at Day 3 with significantly less cells, compared to those from the normal group $(p<0.05)$. The blastocyst development rate was significantly lower in women with overweight and obesity compared to women with normal BMI $(p<0.05)$; but, the percentages of good blastocysts were similar in all studied patients. Pregnancy, implantation and live birth rates were significantly lower in the group of women with overweight and obesity, compared to those women with normal weight $(p<0.05)$. Obese women had significantly more miscarriages compared to those in the other groups $(p<0.05)$.

Conclusions: Our data shows that an increased BMI affects embryo development and significantly reduces the pregnancy, implantation and live birth rates.

Keywords: Body mass index, IVF, pregnancy, implantation, live birth, ART

\section{INTRODUCTION}

Overweight and obesity (defined as a body mass index (BMI) of $25-29.9 \mathrm{~kg} / \mathrm{m}^{2}$ and $\geq 30 \mathrm{~kg} / \mathrm{m}^{2}$, respectively), have become an epidemic and a major public health problem worldwide. Between 1980 and 2013, there was an increase in BMI above the normal level of $25 \mathrm{~kg} / \mathrm{m}^{2}$, from 28.8 to $36.9 \%$ in men and 29.8 to $38 \%$ in women $(\mathrm{Ng}$ et al., 2014), and in 2016, the World Health Organization (WHO) stated that of the world's adult population, 39\% was overweight and $13 \%$ was obese; and of these, $40 \%$ were women with overweight and $13 \%$ women with obesity (WHO, 2016). Additionally, data from the National Health and Nutrition Examination Survey (NCHS) from USA reported that during 2015-2016, Hispanic women had a higher prevalence of obesity $(50.6 \%)$ than non-Hispanic white (38.0\%) and non-Hispanic Asian (14.8\%) women, and this prevalence was similar to the one found in nonHispanic white women (54.8\%) (Hales et al., 2017).

It is evident that there are well-defined disparities in obesity rates between different ethnic and socioeconomic backgrounds, but one of the subpopulations that is mostly affected are women of reproductive age. Obese women have a threefold risk for infertility (Van Der Steeg et al., 2008; Brewer \& Balen, 2010), decline in fecundability (Ramlau-Hansen et al., 2007; Wise et al., 2010), impaired ovulation, poor oocytes and embryo quality (Jungheim \& Moley, 2010; Pandey et al., 2010), and higher cancellation rates (Fedorcsák et al., 2004; Luke et al., 2011a; Mackenna et al., 2017).

The principal effect of an abnormal BMI in women with overweight and obesity is increased levels of lipid storage in adipose tissues and other metabolic organs, which lead to cellular lipid toxicity, inflammation, oxidative stress, and development of metabolic dysfunctions that finally reduce their quality and quantity of life (Snider \& Wood, 2019). In addition, overweight and obesity are associated with alterations to the hypothalamic-pituitary-gonadal-axis leading to menstrual dysfunction, anovulation, uterine bleeding, endometrial pathology, and increased risk of poor obstetrical outcomes, such as preeclamsia, gestational diabetes, induction of labor, surgical delivery, postpartum hemorrhage, fetal macrosomia, and congenital anomalies (Linné, 2004; Catalano \& Ehrenberg, 2006; Stothard et al., 2009; Aly et al., 2010; Kasum et al., 2017).

In recent years, there has been a substantial improvement in quality control and culture systems in ART worldwide that has brought about an increase in implantation and pregnancy rates in those patients undergoing IVF/ICSI cycles; however, it is yet not clear the effect of overweight and obesity on clinical outcomes. Although some authors have reported no negative effects of obesity on IVF outcomes (Dechaud et al., 2006; Maheshwari et al., 2007; Farhi et al., 2010; Mackenna et al., 2017; Ben-Haroush et al., 2018), others have showed an adverse effect of overweight and obesity on pregnancy rates (Fedoresák et al., 2004; Bellver et al., 2010; Luke et al., 2011a; Rittenberg et al., 2011; Moragianni et al., 2012; Kawwass et al., 2016; Luke, 2017; Sampo et al., 2017), implantation rates (Bellver et al., 2010; Moragianni et al., 2012), miscarriages rates (Veleva et al., 2008; Rittenberg et al., 2011; Kawwass et al., 2016), and live birth rates (Bellver et al., 2010; Luke et al., 2011b; Rittenberg et al., 2011; Moragianni et al., 2012; Petersen et al., 2013; Kawwass et al., 2016). A systematic review and meta-analysis of 33 studies and 47,967 IVF/ICSI procedures revealed that overweight or obese women had significantly lower clinical pregnancy and live birth rates, and significantly higher miscarriage rates (Rittenberg et al., 2011). Similar results were reported by Maheshwari et al. (2007), Vural et al. (2015), Kawwass et al. (2016), and Provost et al. (2016). Additionally, a meta-analysis showed that overweight and obese women have a $10 \%$ lower live birth rate when compared to their normal counterparts when undergoing an IVF procedure (Ku et al., 2006). 
The aim of our study was to investigate the relationship between overweight and obesity with clinical outcomes and embryo development in fresh IVF/ICSI cycles.

\section{MATERIALS AND METHODS}

\section{Study design}

This is a retrospective and nonrandomized study based on data analysis from 191 IVF/ICSI cycles with fresh embryo transfer, performed between July 2016 and December 2018 at the Laboratory of Assisted Reproduction of Alcivar Hospital (Guayaquil, Ecuador). BMI was calculated by dividing body mass (weight in kilograms) by the square of body height in meters. All cycles were allocated according to BMI in three groups: normal group: $18.5-24.9 \mathrm{~kg} / \mathrm{m}^{2}$ ( $n=67$ women), overweight group: $25.0-$ $29.9 \mathrm{~kg} / \mathrm{m}^{2}$ ( $n=86$ women) and obesity group: $\geq 30.0 \mathrm{~kg} /$ $\mathrm{m}^{2}$ ( $n=38$ women). We included those patients admitted to autologous IVF and ICSI with one or more mature oocytes recovered and one or more viable embryo obtained. We did not include cases of azoospermia and egg donation.

All participants and their husbands signed informed consents and the Institutional Review Board and the corresponding Ethics Committee from the Alcivar Hospital (Guayaquil, Ecuador) approved the study.

\section{Controlled ovarian stimulation and oocyte collection}

We stimulated the menstrual cycles of patients using recombinant follicle-stimulating hormone ( $\mathrm{rFSH}$ ) (Gonal ${ }^{\circledR}$, Merck Serono laboratories, Ecuador), according to established stimulation protocols, on day 2 of the menstrual cycle until at least two follicles of $\sim 18 \mathrm{~mm}$ in diameter were reached. Oocytes were collected $36 \mathrm{~h}$ after recombinant human chorionic gonadotropin administration (Ovidrel ${ }^{\circledR}$, Merck Sereno laboratories, Ecuador) by transvaginal ultrasound ovum pick-up, with the patient under general anesthesia with $200 \mathrm{mg}$ of Propofol iv (Diprivan ${ }^{\circledR} \quad 1 \% \quad \mathrm{P} / \mathrm{V}$; AstraZeneca Laboratories, UK). During the follicular aspiration procedure, the oocytes were recovered in the Global ${ }^{\circledR}$-HEPES-buffered medium (LifeGlobal) supplemented with $10 \% \mathrm{vol} / \mathrm{vol}$ Serum Substitute Supplement (SSS; Irvine Scientific). After retrieval, cumulus-oocyte complexes were trimmed of excess cumulus cells using sterile needles and cultured in $\sim 150 \mu$ drops of Global ${ }^{\circledR}$-Fertilization medium (LifeGlobal), plus $10 \%$ SSS under oil at $37^{\circ} \mathrm{C}$ in an atmosphere containing $6 \% \mathrm{CO}_{2}, 5 \% \mathrm{O}_{2}$ and $89 \% \mathrm{~N}_{2}$ for 5 hours before the IVF/ICSI procedure.

Insemination, fertilization and embryo culture

The recovered oocytes were assessed for their nuclear maturity, and only metaphase II oocytes were submitted to IVF/ICSI. We inseminated the patients with $50,000-100,000$ motile spermatozoa in $\sim 150 \mu \mathrm{l}$ drops of Global ${ }^{\circledR}$-Fertilization medium $+10 \%$ SSS, where 1 to 5 oocytes were placed. In the ICSI procedures, all collected oocytes were denuded enzymatically off cumulus cells with hyaluronidase (80 IU/ml; LifeGlobal), and injected following routine laboratory procedures.

We confirmed normal fertilization 16-18 hours after insemination/injection by the presence of two pronuclei (day 1 ). The zygotes were individually cultured under mineral oil, in $20-\mu \mathrm{l}$ droplets of $\mathrm{Global}^{\circledR}$ medium (LifeGlobal), supplemented with $10 \% \mathrm{vol} / \mathrm{vol}$ SSS from day 1 to day 3 , in which the embryos were moved to fresh Global $^{\circledR}$ medium and cultured 2 days more up to blastocyst stage. On day 3, the embryos were evaluated for cell number, fragmentation and multinucleation, and on day 5 , for development of blastocyst and expansion. Good quality day-3 embryos were defined as those with 6-8 cells and $\leq 10 \%$ fragmentation. Good quality blastocysts were defined as having an inner cell mass (ICM) and trophectoderm type A or B (Gardner \& Schoolcraft, 1999). The ICM score was evaluated as follows: type $A=$ compact area, many cells present; type $\mathrm{B}=$ cells are loosely grouped. The trophectoderm was scored as follows: type $A=$ many cells forming a tight epithelial network of cells; type $B=$ few cells forming a loose network of cells.

\section{Seminal samples}

On the day of the IVF/ICSI procedure, all patients' partners collected the semen samples by masturbation in aseptic conditions, into sterile cups after 2 days of sexual abstinence. Concentration, progressive motility and morphology from spermatozoa were assessed after semen liquefaction for 30 minutes at room temperature, according to World Health Organization criteria (WHO, 2010). Motile spermatozoa were separated from the seminal plasma by centrifugation at $300 \times \mathrm{g}$ for 10 minutes through 1.0 $\mathrm{ml} 95 \%$ and $45 \%$ Isolate gradients (Irvine Scientific, USA). The pellet was washed once by centrifugation for 5 minutes, and was resuspended in $0.3 \mathrm{ml}$ of Global Fertilization medium $+10 \%$ SSS for IVF/ICSI.

\section{Embryo transfer}

Embryos were transferred on day 5 in all patients using a Rocket Bulb Tip embryo transfer catheter (Rocket Medical, USA) that had been previously washed with culture medium. The catheter was completely filled with culture medium and the blastocysts filled the bottom $10 \mu \mathrm{l}$ of the catheter. All transfers were performed according to the methods previously described by Mansour (2005). The blastocysts that were not transferred were cryopreserved or discarded according to their morphology.

\section{Pregnancy determinations}

Biochemical pregnancy was assessed 14 days after the embryo transfer by measuring the Human Chorionic Gonadotropin beta subunit (hCG-b) in the blood. The clinical pregnancy rate (PR) was determined by transvaginal ultrasonography to detect gestational sacs and fetal heartbeats at approximately 21 and 28 days after transfer, respectively. The implantation rate (IR) was determined by dividing the number of gestational sacs by the number of embryos transferred. Live birth rate (LBR) was determined by dividing the number of cycles that lead to live birth by the total number of transferred cycles.

\section{Statistical Analysis}

The data was statistically analyzed using the $x^{2}$ test, Student's t-test, and multivariate analysis as appropriate, and differences were considered to be significant at $p<0.05$. All statistical analyses were carried out using the statistic package Stata 10 (StataCorp, College Station, TX, USA).

\section{RESULTS}

Our study analyzed 191 fresh IVF/ICSI cycles using non-donor oocytes, of which 67 women had normal weight $(35.1 \%), 86$ were overweight $(45.0 \%)$ and 38 were obese $(19.9 \%)$. The age of the patients and their partners were similar between the evaluated groups (Table 1). No difference was found in duration of ovarian stimulation according to the BMI group; but overweight and obese women used higher doses of rFSH, compared to the normal women group $(p<0.05)$ (Table 1$)$. In regards to seminal samples of patients' husbands, parameters of volume, sperm concentration, progressive motility and sperm morphology were similar between the three groups in the study (Table 2). 
Table 1. Characteristics of patients according to their BMI.

\begin{tabular}{|c|c|c|c|}
\hline & Normal & Overweight & Obesity \\
\hline Cycles & 67 & 86 & 38 \\
\hline BMI (Mean \pm SD) & $22.8 \pm 1.61$ & $27.4 \pm 1.28 *$ & $33.5 \pm 3.76 *, * *$ \\
\hline Female age (years) (Mean \pm SD) & $33.9 \pm 3.48$ & $33.7 \pm 3.86$ & $33.5 \pm 3.47$ \\
\hline Male age (years) (Mean \pm SD) & $35.9 \pm 5.78$ & $37.8 \pm 7.45$ & $39.5 \pm 8.32$ \\
\hline Stimulation days (Mean \pm SD) & $9.0 \pm 1.15$ & $9.2 \pm 1.18$ & $9.1 \pm 1.01$ \\
\hline rFSH (U/L) (Mean $\pm S D)$ & $1683.2 \pm 456.42$ & $1882.1 \pm 422.95 *$ & $2143.8 \pm 337.46^{*}$ \\
\hline
\end{tabular}

$* p<0.05$ in relation to the normal group

$* * p<0.05$ in relation to the overweight group

Table 2. Seminal characteristics in the evaluated groups.

\begin{tabular}{|l|c|c|c|}
\hline & Normal & Overweight & Obesity \\
\hline Semen volume $(\mathrm{ml})($ Mean \pm SD) & $2.5 \pm 1.23$ & $2.4 \pm 1.09$ & $2.5 \pm 1.02$ \\
\hline Sperm concentration $(x 106 / \mathrm{ml})$ & $56.8 \pm 33.96$ & $56.5 \pm 29.59$ & $58.7 \pm 25.58$ \\
\hline Progressive motility $(\%)$ & $24.2 \pm 11.99$ & $24.9 \pm 12.73$ & $27.6 \pm 11.18$ \\
\hline Sperm morphology $(\%)$ & $8.4 \pm 3.21$ & $8.7 \pm 4.59$ & $8.3 \pm 7.07$ \\
\hline
\end{tabular}

$p$ : not significant (NS)

Table 3 summarizes the laboratory results in the study groups. A total of 455, 587 and 288 oocytes were inseminated from normal weight, overweight and obesity groups, respectively. Fertilization rate (2PN) $(87.7 \%, 85.3 \%$ and $84.0 \%)$, percentages of zygotes that underwent cleavage $(97.2 \%, 99.2 \%$ and $98.8 \%)$, and good-quality embryos at day $3(84.0 \%, 82.3 \%$ and $79.9 \%)$ were similar in the three evaluated groups ( $p=$ not significant). However, embryos from overweight and obese women had significantly lower cell numbers compared to those embryos from normal-weight women $(6.7 \pm 1.73$ and $6.8 \pm 1.04$ versus $7.3 \pm 0.79$ cell/embryo $)(p<0.05)$. During extended embryo culture there was a significantly negative effect of BMI above normal values on blastocyst development rate $(p<0.05)$. The quality and expansion degree of blastocysts were no affected by BMI values.

Table 4 shows the clinical outcomes. The mean number of blastocysts available from normal, overweight and obese women were similar $(2.92 \pm 2.02,2.52 \pm 1.71$ and $2.24 \pm 2.45$, respectively). At day 5 , we transferred comparable numbers of embryo $(1.84 \pm 0.37,1.84 \pm 0.38$ and $1.86 \pm 0.31$ ) to women of normal, overweight and obese groups, respectively ( $p=$ not significant). The clinical PR (41.9 and $39.5 \%$ versus $67.2 \%$ ), IR ( 31.8 and $28.2 \%$ versus $53.7 \%$ ) and LBR per transfer ( 52.3 and 39.5 versus $89.6 \%$ ) were significantly lower in those women with overweight and obesity, when compared to those with normal weight $(p<0.05)$. Obese women had a significantly higher miscarriage rate compared to the other groups evaluated $(p<0.05)$. We found one gestational sac was in $24(53.3 \%)$ patients in the normal group, $24(66.7 \%)$ patients of overweight group, and $12(80.0 \%)$ patients of obesity group, respectively. There were two gestational sacs in $21(46.7 \%)$ patients of the normal group, in 12 (33.3\%) patients in the overweight group, and in $3(20.0 \%)$ patients in the obesity group, respectively. Women with normal BMI had significantly more twin pregnancies when compared to those women from other groups $(p<0.05)$.

The multivariate analysis to assesses the possibility to achieve a pregnancy, controlling for BMI, patient age, stimulation days, rFSH doses, number of retrieved oocytes, fertilized oocytes, cleaved embryos at day 3 , number or cells by embryo at day 3, blastocyst formation rate and number of embryos transferred as independent variables showed that only BMI was associated with the possibility of pregnancy success with a determination coefficient $\left(R^{2}\right)$ of 0.345 (Table 5).

\section{DISCUSSION}

In the present study, we analyzed the effecst of BMI on clinical outcomes and perimplantation embryo development in women who underwent IVF/ICSI procedures with their own oocytes. Our data demonstrated that women with BMI above normal values (overweight and obesity groups) had significantly lower pregnancy, implantation and live birth rates during an IVF treatment. These results are very important because they show that overweight and obesity not only reduce the success of an IVF/ICSI procedure, but also delay the time-to-pregnancy and principally the possibility to have a term live born baby.

Obesity is a systemic and tissue-specific condition that can lead to chronic inflammation and oxidative stress, that produces an unregulated and persistent synthesis and secretion of chemokines and cytokines (Sapochnik et al., 2017; Varfolomeev \& Vucic, 2018) by innate immune cells, and adipokines (e.g. leptin and lipocalin) from adipocytes (Garn et al., 2016; Kuroda \& Sakaue, 2017). Cytokines and adipokines are released into the circulation, inducing inflammatory responses in several tissues, including the ovaries (Ouchi et al., 2011; Nteeba et al., 2013; Wang \& Huang, 2015). Wu et al. (2006), Cohen-Fredarow et al. (2014), Field et al. (2014) and Dam et al. (2015) demonstrated that cytokines, chemokines and adipokines play essential roles in steroidogenesis, follicular growth, cumulus expansion after the LH surge, and ovulation; however, alterations in their patterns of synthesis and secretion impair meiotic and cytoplasmic maturation of the oocyte, reducing its developmental competence for fertilization and pre-implantation development. In relation to oxidative stress, obesity promotes the expression of the redox family of NADPH oxidases (NOX), which produced $\mathrm{O}_{2}-$ (from organelles like mitochondria, endoplasmic reticulum and peroxisomes) that is converted to $\mathrm{H}_{2} \mathrm{O}_{2}$ by superoxide dismutase, which may freely move from organelles to the 


\begin{tabular}{|l|c|c|c|}
\hline Table 3. Comparison of laboratory results between the three evaluated groups. & Overweight & Obesity \\
\hline BMI & Normal & 771 & 338 \\
\hline No. total oocytes & 586 & 587 & 288 \\
\hline No. total inseminated oocytes & 455 & $501(85.3)$ & $242(84.0)$ \\
\hline No. total fertilized oocytes (2PN) (\%) & $399(87.7)$ & $497(99.2)$ & $239(98.8)$ \\
\hline No. total cleaved embryo at Day 3 (\%) & $388(97.2)$ & $6.7 \pm 1.73 *$ & $6.8 \pm 1.04 *$ \\
\hline No. cell/embryo at Day 3 (Mean \pm SD) & $7.3 \pm 0.79$ & 82.3 & 79.9 \\
\hline Good-quality embryos at Day 3 (\%) & 84.0 & $40.0 *$ & $40.1 *$ \\
\hline Blastocyst formation rate (\%) & 48.2 & 91.5 & 88.7 \\
\hline Good-quality blastocysts (\%) & 92.9 & 11.6 & 18.6 \\
\hline Full blastocyst (\%) & 13.4 & 83.4 & 78.3 \\
\hline Expanded blastocyst (\%) & 80.2 & 5.0 & 3.1 \\
\hline Hatching blastocyst (\%) & 6.4 & & \\
\hline
\end{tabular}

$* p<0.05$ in relation to normal group

\begin{tabular}{|c|c|c|c|}
\hline BMI & Normal & Overweight & Obesity \\
\hline Cycles & 67 & 86 & 38 \\
\hline No. blastocyst/patient (Mean \pm SD) & $2.92 \pm 2.02$ & $2.52 \pm 1.71$ & $2.24 \pm 2.45$ \\
\hline No. of embryo transferred/patient (Mean \pm SD) & $1.84 \pm 0.37$ & $1.84 \pm 0.38$ & $1.86 \pm 0.31$ \\
\hline Pregnancy rate $(\%)$ & 67.2 & $41.9 *$ & $39.5 *$ \\
\hline Implantation rate $(\%)$ & 53.7 & $31.8 *$ & $28.2 *$ \\
\hline Live birth rate $(\%)$ & 89.6 & $52.3 *$ & $39.5 *$ \\
\hline Miscarriages (\%) & 2.2 & 2.7 & $6.7 *$ \\
\hline Single pregnancy $(\%)$ & 53.3 & 66.7 & 80.0 \\
\hline Twin pregnancy $(\%)$ & $46.7 * *$ & 33.3 & 20.0 \\
\hline
\end{tabular}

$* p<0.05$ in relation to normal group

$* * p<0.05$ in relation to overweight and obesity groups

Table 5. Multivariate logistic regression analysis for clinical pregnancy as a dependent variable.

\begin{tabular}{|l|c|c|c|c|c|}
\hline Independent variable & B & SE & $\boldsymbol{p}$ & \multicolumn{2}{c|}{ Confidence interval at 95\% } \\
\hline BMI (\%) & -0.04 & 0.02 & 0.017 & -0.08 & -0.01 \\
\hline Age of patient (years) & -0.04 & 0.02 & 0.072 & -0.08 & 0.00 \\
\hline Stimulation days & -0.07 & 0.08 & 0.375 & -0.23 & 0.09 \\
\hline rFSH doses (U/L) & 0.01 & 0.01 & 0.555 & -0.00 & 0.01 \\
\hline No. of retrieved oocytes & -0.04 & 0.03 & 0.162 & -0.09 & 0.02 \\
\hline No. of inseminated oocytes & -0.08 & 0.05 & 0.131 & -0.20 & 0.03 \\
\hline Fertilized oocytes (\%) & 0.16 & 0.18 & 0.369 & -0.19 & 0.53 \\
\hline Cleaved embryos at Day 3 (\%) & 0.02 & 0.19 & 0.921 & -0.36 & 0.40 \\
\hline No. cell/embryo at Day 3 (Mean+SD) & 0.17 & 0.10 & 0.090 & -0.03 & 0.37 \\
\hline Blastocyst formation rate (\%) & -0.07 & 0.05 & 0.147 & -0.17 & 0.03 \\
\hline No. embryo transferred & -0.04 & 0.36 & 0.273 & -1.12 & 0.33 \\
\hline
\end{tabular}

Dependent variable: Pregnancy Rate. $B=$ coefficient of regression, $S E=$ standard error, $p=$ probability, $N=$ sample size. $R^{2}=0.345, \mathrm{P}=0.0047, N=191$.

cytoplasm of the cell, thus increasing the expression of pro-inflammatory cytokines (Rimessi et al., 2016; Chong et al., 2017; Mailloux, 2018).
In this study, overweight and obese females had significant gonadotrophin consumption in comparison with normal weight women but did not find any significant 
differences in stimulation days. Similar results were reported by Maheshwari et al. (2007), Koatz \& de Souza (2013), Ozekinci et al. (2015) and Ben-Haroush et al. (2018). These higher doses used in overweight and obese patients would be induced by an inhibitory effect of elevated leptin, which impairs ovarian responsiveness to gonadotrophin stimulation, requiring more medication or also to an increased clearance of the drugs by the excess of fat tissue (Souter et al., 2011).

In regards to laboratory results, there were no differences in fertilization rates, cleavage and good-quality embryo at day 3 across the BMI categories. However, patients with overweight and obesity had embryos at day 3 with significantly less cell/embryo and lower blastocyst formation rate when compared to patients with normal BMI, similar to what was previously reported by Comstock et al. (2015) and Leary et al. (2015). Excess free fatty acids in overweight and obese females affect the oocyte and its organelles through a lipotoxicity effect that will ultimately have a negative impact on the future embryo (Broughton \& Moley, 2017). Obesity alters mitochondrial function in the oocyte, disrupting its architecture with fewer cristae, more vacuoles, and evidence of swelling. In addition, there are changes in their distribution with clumping throughout the ooplasm instead of a perinuclear localization (Grindler \& Moley, 2013). Likewise, oocytes from women with obesity have showed disarrayed meiotic spindles with misaligned metaphase chromosomes (Machtinger et al., 2012), smaller size, minor oolemma diameter, and minor zona pellucida thickness than oocytes from women with normal BMI (Atzmon et al., 2017). In addition, human oocytes from overweight and obese patients have reduced glucose use and elevated endogenous triglyceride levels that significantly affect the oocyte competence, and its capacity of development to the blastocyst stage (Leary et al., 2015). These changes to the glucose and triglyceride metabolism are also reported in blastocysts from overweight and obese patients, and this would be one of the factors that reduces the proportion of blastocysts obtained during an IVF treatment in these patients (Comstock et al., 2015; Leary et al., 2015). Moreover, Yamada et al. (2013) evaluating the blastocyst formation rate according to the number of cells/embryos at day 3 in IVF/ICSI cycles reported that those embryos with $<7$ cells had a significantly reduced chance to reach the blastocyst stage, which was also reported during our study involving patients with BMI above normal values; and these minors percentages of blastocysts were independent of goodquality embryos at day 3 that was similar across the BMI categories. Herrero et al. (2013) and Leary et al. (2015) reported similar results in overweight/obese women whom embryos were less likely to reach the blastocyst stage; and those that did develop into blastocysts showed accelerated preimplantation development with fewer trophectoderm cells. Finally, it is important to highlight that our data demonstrate that the effect of overweight and obesity on oocyte competence and embryo development would start post-fertilization and not after day 3 of the cleavage stage, as per suggested by Comstock et al. (2015).

About clinical outcomes, all patients received similar numbers of fresh embryos in the blastocyst stage; however, there was a significant decline in PR, IR and LBR in overweight and obese patients compared to those with normal BMI. These data are similar to those reported by Vural et al. (2015), Provost et al. (2016), and Kudesia et al. (2018) concerning pregnancy rates; Moragianni et al. (2012) concerning implantation rates; and Bellver et al. (2010), Sifer et al. (2014), Kasum et al. (2017), Russo et al. (2017), and Supramaniam et al. (2018) concerning live birth rates. Likewise, our data shown that just those obese patients had significantly more miscarriages compared to other two evaluated groups, being these results similar to those reported in previous studies by Maheshwari et al. (2007) and Supramaniam et al. (2018). Additionally, these update results are in accordance with two big previous meta-analysis based on 47,967 and 682,532 cycles, which demonstrated that overweight and obesity have a significant deleterious effect on PR (Rittenberg et al., 2011) and LBR (Sermondade et al., 2019) following IVF.

Mechanisms such as impaired ovarian folliculogenesis, oocyte quality, embryonic development and endometrial receptivity have been proposed as an explanation to poor reproductive outcomes in overweight and obese women. Studies in human and animal models have shown that an altered function of the hypothalamic-pituitary axis associated with high insulin, androgen, estrogen, and leptin levels impair ovarian folliculogenesis, and therefore oocyte quality (Tortoriello et al., 2004; Jungheim \& Moley, 2010). As explained above, oocyte and perimplantation embryo development are affected by obesity, through metabolic alterations to lipids, proteins and growth factors that lead to an increased oxidative stress and unbalance of certain free fatty acids that impair granulosa cells function (Lin et al., 2017), alignment of metaphase chromosomes in the meiotic spindles of oocytes (Machtinger et al., 2012), and glucose and triglycerides metabolism in blastocysts (Leary et al., 2015).

On the other hand, an altered endometrial receptivity could be responsible for decreased clinical outcomes in overweight/obese females such as we report in our study. Regarding controversial data whether an abnormal BMI affects the endometrium, Crosby et al. (2017) showed a significant positive correlation between female BMI and endometrial thickness (but not with the pregnancies), and such thickening is in the relative hyperestrogenic state due to excess aromatization in the adipose tissue. Likewise, it has been shown that obesity impairs endometrial decidualization, which is necessary for uterine receptivity in animal models (Rhee et al., 2016), in immortalized human endometrial stromal cell lines triggered to undergo decidualization (Hill et al., 2007; Rhee et al., 2016), and in humans as well (Bellver et al., 2013). An important factor that would be influencing and playing a key role in endometrial receptivity is leptin (Catteau et al., 2016). Human endometrial endothelial cells in culture express the leptin-receptor, through which leptin regulates the remodeling of the human endometrial epithelium (Gonzalez \& Leavis, 2001) stimulating proliferation and apoptotic cell pathways in vitro (Tanaka \& Umesaki, 2008). In addition, Bellver et al. (2011), analyzing gene expression during the window of implantation, showed a different endometrial gene expression among obese patients compared to controls with normal weight, being some of these genes previously related to implantation and unexplained infertility.

In contrast with our results, previous studies involving overweight/obese females that underwent in vitro fertilization with their own oocytes did not demonstrated lower PR, IR, and LBR rates compared to normal-weight females (Vilarino et al., 2011; Legge et al., 2014; Ozekinci et al., 2015; Atzmon et al., 2017; Friedler et al., 2017; Mackenna et al., 2017; Sampo et al., 2017; Di Gregorio et al., 2019). In these studies, it is important to emphasize that the embryo transfers were made at day 2 or 3 of the development, when the embryonic genome had not yet been activated, and its potential to reach blastocyst stage is unknown, which did not show the effects of overweight and obesity on clinical outcomes. Besides, embryo transfer in earlier developmental stage shows reduced implantation potential when compared with the transfer in blastocyst stage, because the latter enables a better synchronization between the embryo developmental stage and the uterine environment (Quea et al., 2007). Furthermore, ethnicity could be playing a possible role on ART results, since in 
most of these studies did not have Hispanic women among their subjects, and anthropometrics measures can be dramatically different among several ethnicities. In 20112013 the prevalence of overweight/obesity in women of reproductive age in Ecuador was $56.8 \%$, with a height average of $152 \mathrm{~cm}$ (Freire et al., 2013); whereas in the USA it was $38.3 \%$ in women of all the races, and $45.7 \%$ in Hispanic women during 2011-2014 (Ogden et al., 2015). In ART, the prevalence of overweight/obese women that underwent an in-vitro fertilization procedure is variable and dependent on the site where the study was carried out, observing values that oscillate from $28 \%$ (Sampo et al., 2017) all the way up to $54.4 \%$ (Di Gregorio et al., 2019), and now $64.9 \%$ in our study. These differences correspond to nutritional changes, bad quality and schedules of food, and new lifestyles that lead to an increase in overweight, obesity, and their complications.

Finally, it is important to highlight that the main limitation of our study lies in its retrospective design and the inherent risk for undetected selection bias, and the limited number of cycles. Well-designed prospective studies, in which the variables are controlled and include a greater number of cycles, are needed in order to corroborate the results reported in this retrospective study.

In conclusion, our data shows that overweight and obesity significantly decreases pregnancy, implantational and live birth rates in women undergoing an IVF procedure. Interventions, including weight loss, physical activity, and dietary modification are highly recommended for overweight/obese women wishing to conceive, especially those wishing to have a term liveborn baby.

\section{CONFLICT OF INTERESTS}

There is no conflict of interest

\section{Corresponding author:}

Javier García-Ferreyra

Laboratory of Assisted Reproduction

Guayaquil, Ecuador

Email: jgarciaf@hotmail.com

\section{REFERENCES}

Aly H, Hammad T, Nada A, Mohamed M, Bathgate S, El-Mohandes $A$. Maternal obesity, associated complications and risk of prematurity. J Perinatol. 2010;30:447-51. PMID: 19693021 DOI: $10.1038 /$ jp.2009.117

Atzmon Y, Shoshan-Karchovsky E, Michaeli M, Aslih N, Shrem G, Ellenbogen A, Shalom-Paz E. Obesity results with smaller oocyte in in vitro fertilization/intracytoplasmic sperm injection cycles-a prospective study. J Assist Reprod Genet. 2017;34:1145-51. PMID: 28624860 DOI: 10.1007/ s10815-017-0975-6

Bellver J, Ayllon Y, Ferrando M, Melo M, Goyri E, Pellicer A, Remohi J, Meseguer M. Female obesity impairs in vitro fertilization outcome without affecting embryo quality. Fertil Steril. 2010; 93:447-54. PMID: 19171335 DOI: 10.1016/j. fertnstert.2008.12.032

Bellver J, Martínez-Conejero JA, Labarta E, Alamá P, Melo MA, Remohí J, Pellicer A, Horcajadas JA. Endometrial gene expression in the window of implantation is altered in obese women especially in association with polycystic ovary syndrome. Fertil Steril. 2011; 95:2335-41. PMID: 21481376 DOI: $10.1016 /$ j.fertnstert.2011.03.021
Bellver J, Pellicer A, García-Velasco JA, Ballesteros A, Remohí J, Meseguer M. Obesity reduces uterine receptivity: clinical experience from 9,587 first cycles of ovum donation with normal weight donors. Fertil Steril. 2013;100:1050-8. PMID: 23830106 DOI: 10.1016/j.fertnstert.2013.06.001

Ben-Haroush A, Sirota I, Salman L, Son WY, Tulandi T, Holzer $\mathrm{H}$, Oron $\mathrm{G}$. The influence of body mass index on pregnancy outcome following single-embryo transfer. J Assist Reprod Genet. 2018;35:1295-300. PMID: 29808381 DOI: $10.1007 / \mathrm{s} 10815-018-1186-5$

Brewer CJ, Balen AH. The adverse effects of obesity on conception and implantation. Reproduction. 2010;140:34764. PMID: 20395425 DOI: 10.1530/REP-09-0568

Broughton $\mathrm{DE}$, Moley $\mathrm{KH}$, Obesity and female infertility: potential mediators of obesity's impact. Fertil Steril. 2017;107:840-7. PMID: 28292619 DOI: 10.1016/j.fertnstert.2017.01.017

Catalano PM, Ehrenberg HM. The short- and long-term implication of maternal obesity on the mother and her offspring. BJOG. 2006;113:1126-33. PMID: 16827826 DOI: 10.1111/j.1471-0528.2006.00989.x

Catteau $A$, Caillon $H$, Barrière $P$, Denis MG, Masson $D$, Fréour T. Leptin and its potential interest in assisted reproduction cycles. Hum Reprod Update. 2016;22:320-41. 2016;22:320-41. PMID: 26663219 DOI: 10.1093/humupd/dmv057

Chong WC, Shastri MD, Eri R. Endoplasmic reticulum stress and oxidative stress: a vicious nexus implicated in bowel disease pathophysiology. Int J Mol Sci. 2017;18:771. PMID: 28379196 DOI: $10.3390 /$ ijms18040771

Cohen-Fredarow A, Tadmor A, Raz T, Meterani N, Addadi $\mathrm{Y}$, Nevo N, Solomonov I, Sagi I, Mor G, Neeman M, Dekel N. Ovarian dendritic cells act as a double-edged pro-ovulatory and anti-inflammatory sword. Mol Endocrinol. 2014;28:103954. PMID: 24825398 DOI: 10.1210/me.2013-1400

Comstock IA, Kim S, Behr B, Lathi RB. Increased body mass index negatively impacts blastocyst formation rate in normal responders undergoing in vitro fertilization. J Assist Reprod Genet. 2015;32:1299-304. PMID: 26109331 DOI: $10.1007 / \mathrm{s} 10815-015-0515-1$

Crosby D, O'Brien Y, Glover L, Martyn F, Windgfield M. Influence of body mass index on the relationship between endometrial thickness and pregnancy outcome in single blastocyst frozen embryo transfer cycles. Hum Fertil. 2018:1-6. PMID: 30221570 DOI: 10.1080/14647273.2018.1504324

Dam PTM, Jang Y-J, Chun S-Y, Park J-I, Moon W-J, Cho $\mathrm{M}-\mathrm{K}$. Cumulus cell-expressed type I interferons induce cumulus expansion in mice. Biol Reprod. 2015;92:20. PMID: 25429090 DOI: $10.1095 /$ biolreprod.114.122770

Dechaud H, Anahory T, Reyftmann L, Loup V, Hamamah S, Hedon B. Obesity does not adversely affect results in patients who are undergoing in vitro fertilization and embryo transfer. Eur J Obstet Gynecol Reprod Biol. 2006;127:8893. PMID: 16417960 DOI: 10.1016/j.ejogrb.2005.12.009 
Di Gregorio LM, Zambrotta E, Di Guardo F, Gulino FA, Musmeci G, Capriglione S, Angioli R, Palumbo M. Effects of Body Mass Index and Biochemical Lipid Levels on Reproductive Outcomes during An Intracytoplasmic Sperm Injection: A Retrospective Study. Int J Fertil Steril. 2019;13:190-5. PMID: 31310072 DOI: 10.22074/ijfs.2019.5614

Farhi J, Ben-Haroush A, Sapir O, Fisch B, Ashkenazi J. High-quality embryos retain their implantation capability in overweight women. Reprod BioMed Online. 2010;21:70611. PMID: 20880747 DOI: 10.1016/j.rbmo.2010.06.040

Fedorcsák P, Dale PO, Storeng R, Ertzeid G, Bjercke S, OIdereid N, Omland AK, Abyholm T, Tanbo T. Impact of overweight and underweight on assisted reproduction treatment. Hum Reprod. 2004;19:2523-8 PMID: 15319380 DOI: $10.1093 /$ humrep/deh485

Field SL, Dasgupta T, Cummings M, Orsi NM. Cytokines in ovarian folliculogenesis, oocyte maturation and luteinisation. Mol Reprod Develop. 2014;81:284-314. PMID: 24273059 DOI: $10.1002 / \mathrm{mrd} .22285$

Freire WB, Ramírez MJ, Belmont P, Mendieta MJ, Silva MK, Romero N, Sáenz K, Piñeiros P, Gómez LF, Monge R. Resumen Ejecutivo. Tómo I. Encuesta Nacional de Salud y Nutrición del Ecuador 2013. ENSANUT-ECU 2011-2013 Ministerio de Salud/Instituto Nacional de Estadística y Censos. Quito, Ecuador; 2013.

Friedler S, Cohen O, Liberty G, Saar-Ryss B, Meltzer S, Lazer T. Should high BMI be a reason for IVF treatment denial?. Gynecol Endocrinol. 2017;33:853-6. PMID: 28531369 DOI: $10.1080 / 09513590.2017 .1327042$

Gardner DK, Schoolcraft WB. In vitro culture of human blastocysts. In: Jansen R, Mortimer D, eds. Towards Reproductive Certainly: Infertility and Genetics Beyond; The Plenary Proceedings of the 11th World Congress on In Vitro Fertilization and Human Reproductive Genetics. Pearl River: Parthenon Press; 1999. p.378-88.

Garn H, Bahn S, Baune BT, Binder EB, Bisgaard H, Chatila TA, Chavakis T, Culmsee C, Dannlowski U, Gay S, Gern J, Haahtela T, Kircher T, Müller-Ladner U, Neurath MF, Preissner KT, Reinhardt C, Rook G, Russell S, Schemeck B, et al. Current concepts in chronic inflammatory diseases: interactions between microbes, cellular metabolism and inflammation. J Allergy Clin Immunol. 2016; 138:47- 56. PMID: 27373325 DOI: $10.1016 /$ j.jaci.2016.02.046

Gonzalez RR, Leavis P. Leptin upregulates beta3-integrin expression and interleukin-1beta, upregulates leptin and leptin receptor expression in human endometrial epithelial cell cultures. Endocrine. 2001;16:21-8. PMID: 11822823 DOI: $10.1385 /$ ENDO: $16: 1: 21$

Grindler NM, Moley KH. Maternal obesity, infertility and mitochondrial dysfunction: potential mechanisms emerging from mouse model systems. Mol Hum Reprod. 2013; 19: 486-94. PMID: 23612738 DOI: 10.1093/molehr/gat026

Hales CM, Carroll MD, Fryar CD, Ogden CL. Prevalence of Obesity Among Adults and Youth: United States, 20152016. NCHS Data Brief. 2017;288:1-8. PMID: 29155689
Herrero J, Tejera A, Albert C, Vidal C, de los Santos MJ, Meseguer M. A time to look back: analysis of morphokinetic characteristics of human embryo development. Fertil Steril. 2013; 100:1602-9. PMID: 24083877 DOI: 10.1016/j. fertnstert.2013.08.033

Hill MJ, Uyehara CF, Hashiro GM, Frattarelli JL. The utility of serum leptin and follicular fluid leptin, estradiol, and progesterone levels during an in vitro fertilization cycle. J Assist Reprod Genet. 2007;24:183-8. PMID: 17333366 DOI: $10.1007 / \mathrm{s} 10815-007-9106-0$

Jungheim ES, Moley KH. Current knowledge of obesity's effects in the pre- and periconceptional periods and avenues for future research. Am J Obstet Gynecol. 2010; 203: 525-30. PMID: 20739012 DOI: 10.1016/j.ajog.2010.06.043

Kasum M, OreŠkovic S, Cehic E, Lila A, Ejubovic E, Soldo $D$. The role of female obesity on in vitro fertilization outcomes. Gynecol Endocrinol. 2017;34:184-8. PMID: 29037105 DOI: $10.1080 / 09513590.2017 .1391209$

Kawwass JF, Kulkarni AD, Hipp HS, Crawford S, Kissin DM, Jamieson DJ. Extremities of body mass index and their association with pregnancy outcomes in women undergoing in vitro fertilization in the United States. Fertil Steril. 2016;106:174250. PMID: 27666564 DOI: 10.1016/j.fertnstert.2016.08.028

Koatz JG, de Souza MCB. Obese women and in vitro fertilization: results. JBRA Assist Reprod. 2013;17:353-6.

Ku SY, Kim SD, Jee BC, Suh CS, Choi YM, Kim JG, Moon SY, $\mathrm{Kim} \mathrm{SH}$. Clinical efficacy of body mass index as predictor of in vitro fertilization and embryo transfer outcomes. J Korean Med Sci. 2006;21:300-3. PMID: 16614518 DOI: $10.3346 / \mathrm{jkms} .2006 .21 .2 .300$

Kudesia R, Wu H, Hunter Cohn K, Tan L, Lee JA, Copperman $A B$, Yurttas Beim $P$. The effect of female body mass index on in vitro fertilization cycle outcomes: a multi-center analysis. J Assisted Reprod Genet. 2018;35:2013-23. PMID: 30132171 DOI: $10.1007 /$ s10815-018-1290-6

Kuroda M, Sakaue H. Adipocyte death and chronic inflammation in obesity. J Med Investig. 2017;64:193-6. PMID: 28954980 DOI: $10.2152 /$ jmi.64.193

Leary C, Leese HJ, Sturmey RG. Human embryos from overweight and obese women display phenotypic and metabolic abnormalities. Hum Reprod. 2015;30:122-32. PMID: 25391239 DOI: 10.1093/humrep/deu276

Legge A, Bouzayen R, Hamilton L, Young D. The impact of maternal body mass index on in vitro fertilization outcomes. J Obstet Gynaecol. 2014;36:613-9. PMID: 25184980 DOI: 10.1016/S1701-2163(15)30541-7

Lin XH, Wang $\mathrm{H}$, Wu DD, Ullah K, Yu TT, Ur Rahman T, Huang HF. High leptin level attenuates embryo development in overweight/ obese infertile women by inhibiting proliferation and promotes apoptosis in granule cell. Horm Metab Res. 2017;49:534-41. PMID: 28561185 DOI: 10.1055/s-0043-107617

Linné Y. Effects of obesity on women's reproduction and complications during pregnancy. Obes Rev. 2004;5:137-43. PMID: 15245382 DOI: 10.1111/j.1467-789X.2004.00147.x 
Luke B, Brown MB, Missmer SA, Bukelmez O, Leach $R$, Stern JE; Society for Assisted Reproductive Technology writing group. The effect of increasing obesity on the response to and outcome of assisted reproductive technology: a national study. Fertil Steril. 2011a;96:820-5. PMID: 21821244 DOI: $10.1016 / j$.fertnstert.2011.07.1100

Luke B, Brown MB, Stern JE, Missmer SA, Fujimoto VY, Leach R; SART Writing Group. Female obesity adversely affects assisted reproductive technology (ART) pregnancy and live birth rates. Hum Reprod. 2011b;26:245-52. PMID: 21071489 DOI: $10.1093 /$ humrep/deq306

Luke B. Adverse effect of female obesity and interaction with race on reproductive potential. Fertil Steril. 2017;107:868-77. PMID: 28366413 DOI: $10.1016 / j$.fertnstert.2017.02.114

Machtinger R, Combelles CM, Missmer SA, Correia KF, Fox $\mathrm{JH}$, Racowsky $\mathrm{C}$. The association between severe obesity and characteristics of failed fertilized oocytes. Hum Reprod. 2012; 27: 3198-3207. PMID: 22968161 DOI: 10.1093/ humrep/des308

Maheshwari A, Stofberg L, Bhattacharya S. Effect of overweight and obesity on assisted reproductive technology-a systematic review. Hum Reprod Update. 2007;13:433-44. PMID: 17584821 DOI: 10.1093/humupd/dmm017

Mackenna A, Schwarze JE, Croby JA, Zegers-Hochschild F. Outcome of assisted reproductive technology in overweight and obese women. JBRA Assist Reprod. 2017;21:79-83. PMID: 28609272 DOI: 10.5935/1518-0557.20170020

Mailloux RJ. Mitochondrial Antioxidants and the Maintenance of Cellular Hydrogen Peroxide Levels. Oxid Med Cell Longev. 2018;2018:7857251. PMID: 30057684 DOI: $10.1155 / 2018 / 7857251$

Mansour R. Minimizing embryo expulsion after embryo transfer: a randomized controlled study. Hum Reprod. 2005;20:170-4. PMID: 15567883 DOI: 10.1093/humrep/ deh573

Moragianni VA, Jones S-ML, Ryley DA. The effect of body mass index on the outcomes of first assisted reproductive technology cycles. Fertil Steril. 2012;98:102-8. PMID: 22584023 DOI: 10.1016/j.fertnstert.2012.04.004

$\mathrm{Ng} \mathrm{M}$, Fleming $\mathrm{T}$, Robinson $\mathrm{M}$, Thomson $\mathrm{B}$, Graetz $\mathrm{N}$, Margono C, Mullany EC, Biryukov S, Abbafati C, Abera SF, Abraham JP, Abu-Rmeileh NM, Achoki T, AlBuhairan FS, Alemu ZA, Alfonso R, Ali MK, Ali R, Guzman NA, Ammar W, et al. Global, regional, and national prevalence of overweight and obesity in children and adults during 1980-2013: a systematic analysis for the Global Burden of Disease Study 2013. Lancet. 2014;384:76681. PMID: 24880830 DOI: 10.1016/S0140-6736(14)60460-8

Nteeba J, Ortinau LC, Perfield JW, Keating AF. Diet-induced obesity alters immune cell infiltration and expression of inflammatory cytokine genes in mouse ovarian and peri-ovarian adipose depot tissues. Mol Reprod Develop. 2013;80:948-58. PMID: 24038509 DOI: 10.1002/ mrd.22231

Ogden CL, Carroll MD, Fryar CD, Flegal KM. Prevalence of Obesity Among Adults and Youth: United States, 20112014. NCHS Data Brief. 2015;219:1-8. PMID: 26633046
Ouchi N, Parker JL, Lugus JJ, Walsh K. Adipokines in inflammation and metabolic disease. Nat Rev Immunol. 2011;11:85-97. PMID: 21252989 DOI: 10.1038/nri2921

Ozekinci M, Seven A, Olgan S, Sakinci M, Keskin U, Ermar Akar M, Temel Ceyhan S, Ergun A. Does obesity have detrimental effects on IVF treatment outcomes?. BMC Women's Health. 2015;15:1-7. PMID: 26285703 DOI: 10.1186/ s12905-015-0223-0

Pandey S, Pandey S, Maheshwari A, Bhattacharya S. The impact of female obesity on outcome of fertility treatment. J Hum Reprod. Sci 2010;3:62-7. PMID: 21209748 DOI: 10.4103/0974-1208.69332

Petersen GL, Schmidt L, Pinborg A, Kamoer-Jørgensen M. The influence of female and male body mass index on live birth after assisted reproductive technology treatment: a nationwide register-based cohort study. Fertil Steril. 2013;99:1654-62. PMID: 23394781 DOI: 10.1016/j.fertnstert.2013.01.092

Provost MP, Acharya KS, Acharya CR, Yeh JS, Steward RG, Eaton JL, Goldfarb JM, Muasher SJ. Pregnancy outcomes decline with increasing body mass index: analysis of 239,127 fresh autologous in vitro fertilization cycles from the 2008-2010 Society for Assisted Reproductive Technology registry. Fertil Steril. 2016;105:663-9. PMID: 26627120 DOI: 10.1016/j. fertnstert.2015.11.008

Quea G, Romero K, García-Velasco JA. Extended embryo culture to increase implantation rate. Reprod Biomed Online. 2007;14:375-83. PMID: 17359595 DOI: 10.1016/ S1472-6483(10)60882-6

Ramlau-Hansen $\mathrm{CH}$, Thulstrup AM, Nohr EA, Bonde JP, Sorensen TI, Olsen J. Subfecundity in overweight and obese couples. Hum Reprod. 2007;22:1634-7. PMID: 17344224 DOI: $10.1093 /$ humrep/dem035

Rhee JS, Saben JL, Mayer AL, Schulte MB, Asghar Z, Stephens $\mathrm{C}$, Chi MM, Moley KH. Diet-induced obesity impairs endometrial stromal cell decidualization: a potential role for impaired autophagy. Hum Reprod. 2016;31:1315-26. PMID: 27052498 DOI: 10.1093/humrep/dew048

Rimessi A, Previati M, Nigro F, Wieckowsi MR, Pinton P. Mitochondrial reactive oxygen species and inflammation: molecular mechanisms, diseases and promising therapies. Int J Biochem and Cell Biol. 2016;81:281-93. PMID: 27373679 DOI: $10.1016 /$ j.biocel.2016.06.015

Rittenberg V, Seshadri S, Sunkara SK, Sobaleva S, Oteng-Ntim E, El-Toukhy T. Effect of body mass index on IVF treatment outcome: an updated systematic review and meta-analysis. Reprod Biomed Online. 2011;23:421-39. PMID: 21885344 DOI: 10.1016/j.rbmo.2011.06.018

Russo M, Ates S, Shaulov T, Dahan MH. Morbid obesity and pregnancy outcomes after single blastocyst transfer: a retrospective, North America study. J Assist Reprod Genet. 2017;34:4517. PMID: 28190215 DOI: 10.1007/s10815-017-0883-9

Sampo AV, Palena C, Ganzer L, Maccari V, Estofán G, Hernández $M$. The adverse effect of overweight in assisted reproduction treatment outcomes. JBRA Assist Reprod. 2017;21:2126. PMID: 28837030 DOI: $10.5935 / 1518-0557.20170041$ 
Sapochnik M, Fuertes M, Arzt E. Programmed cell senescence: role of IL-6 in the pituitary. J Mol Endocrinol. 2017;58:R241-R53. PMID: 28381401 DOI: 10.1530/JME-17-0026

Sermondade N, Huberlant S, Bourhis-Lefebvre V, Arbo E, Gallot $\mathrm{V}$, Colombani $\mathrm{M}$, Fréour $\mathrm{T}$. Female obesity in negatively associated with live birth rate following IVF: a systematic review and meta-analysis. Hum Reprod Update. 2019;25:439-51. PMID: 30941397 DOI: 10.1093/humupd/dmz011

Sifer C, Herbemont C, Adda-Herzog E, Sermondade N, Dupont C, Cedrin-Durnerin I, Poncelet C, Levy R, Grynberg M, Hugues JN. Clinical predictive criteria associated with live birth following elective single embryo transfer. Eur J Obstet Gynecol Reprod Biol. 2014;181:229-32. PMID: 25171268 DOI: $10.1016 /$ j.ejogrb.2014.08.004

Snider AP, Wood JR. Obesity induces ovarian inflammation and reduces oocyte quality. Reproduction. 2019;158:R79-R90. PMID: 30999278 DOI: 10.1530/REP-18-0583

Souter I, Baltagi LM, Kuleta D, Meeker JD, Petrozza JC. Women, weight, and fertility: the effect of body mass index on the outcome of superovulation/intrauterine insemination cycles. Fertil Steril. 2011;95:1042-7. PMID: 21195401 DOI: 10.1016/j.fertnstert.2010.11.062

Stothard KJ, Tennant PWG, Bell R. Maternal overweight and obesity and the risk of congenital anomalies. Heal San Fr. 2009;301;636-50. PMID: 19211471 DOI: 10.1001/ jama.2009.113

Supramaniam PR, Mittal M, McVeigh E, Lim LN. The correlation between raised body mass index and assisted reproductive treatment outcomes: a systematic review and meta-analysis of the evidence. Reprod Health. 2018;15:34. PMID: 29486787 DOI: 10.1186/s12978-018-0481-z

Tanaka $\mathrm{T}$, Umesaki $\mathrm{N}$. Leptin regulates the proliferation and apoptosis of human endometrial epithelial cells. Int J Mol Med. 2008;22:683-9. PMID: 18949391 DOI: 10.3892/ ijmm_00000073

Tortoriello DV, McMinn J, Chua SC. Dietary-induced obesity and hypothalamic infertility in female DBA/2 J mice. Endocrinology. 2004;145:1238-47. PMID: 14670988 DOI: 10.1210/en.2003-1406

Van der Steeg JW, Steures P, Eijkemans MJ, Habbema JD, Hompes PG, Burggraaff JM, Oosterhuis GJ, Bossuyt PM, Van der Veen $\mathrm{F}$, Mol BW. Obesity affects spontaneous pregnancy chances in subfertile, ovulatory women. Hum Reprod. 2008;23:3248. PMID: 18077317 DOI: 10.1093/humrep/dem371
Varfolomeev $\mathrm{E}$, Vucic $\mathrm{D}$. Intracellular regulation of TNF activity in health and disease. Cytokyne. 2018;101:26-32. DOI: $10.1016 /$ j.cyto.2016.08.035

Veleva Z, Titinem A, Visika S, Hydén-Granskog C, Tomás C, Martikainen $\mathrm{H}$, Tapanainen JS. High and low BMI increase the risk of miscarriage after IVF/ICSI and FET. Hum Reprod. 2008;23:878-84. PMID: 18281684 DOI: 10.1093/ humrep/den017

Vilarino FL, Christofolini DM, Rodrigues D, de Souza AM, Christofolini J, Bianco B, Barbosa CP. Body mass index and fertility: is there a correlation with human reproduction outcomes?. Gynecol Endocrinol. 2011;27:232-6. PMID: 20528211 DOI: $10.3109 / 09513590.2010 .490613$

Vural F, Vural B, Çakiroglu Y. The role of Overweight and Obesity in In Vitro Fertilization Outcomes of Poor Ovarian Responders. Biomed Res Int. 2015;2015:781543. PMID: 26106614 DOI: $10.1155 / 2015 / 781543$

Wang Y, Huang F. N-3 polyunsaturated fatty acids and inflammation in obesity: local effect and systemic benefit. BioMed Res Int. 2015;2015:581469. PMID: 26339623 DOI: $10.1155 / 2015 / 581469$

Wise LA, Rothman KJ, Mikkelsen EM, Sorensen HT, Riis A, Hatch EE. An internet-based prospective study of body size and time-to-pregnancy. Hum Reprod. 2010;25:253-64. PMID: 19828554 DOI: 10.1093/humrep/dep360

WHO -World Health Organization. WHO Laboratory manual for examination and processing. 5th edition 2010.

WHO -World Health Organization. Global Health Observatory Data. Obesity and overweight fact sheet; 2016. Available at: http://www.who.int/mediacentre/factsheets/ fs311/en/.

Wu R, Fujii S, Sini I, Van der Hoek KH, Jasper MJ, Ryan NK, Robker RL, Robertson SA, Norman RJ. Ovarian leukocyte distribution and cytokine/chemokine mRNA expression in follicular fluid cells in women with polycystic ovary syndrome. Hum Reprod. 2006;22:527-35. PMID: 16997933 DOI: $10.1093 /$ humrep/del371

Yamada Y, Yoshida A, Tanaka M, Suzuki H, Sakakibara K, Tanigiwa S. Good-quality blastocyst formation rate expected from embryo on the day3. Fertil Steril. 2013;100:S2545. DOI: $10.1016 /$ j.fertnstert.2013.07.1198 